\title{
In vitro Effects of Polysaccharide Gel Extracted from Durian Rinds (Durio zibethinus L.) on the Enzymatic Activities of MMP-2, MMP-3 and MMP-9 in Canine Chondrocyte Culture
}

\author{
Waranee Pradit, Korakot Nganvongpanit, Puntita Siengdee, Kittisak Buddhachat, Maslin Osathanunkul, \\ and Siriwadee Chomdej
}

\begin{abstract}
Osteoarthritis (OA) is a major joint disease found in animals, especially dogs, with $20 \%$ rate of incidence. The alternative therapy using medicinal plants has been of interest for a long time. Polysaccharide gel (PG) extracted from durian rinds (Durio zibethinus L.) was first isolated in 1998 for use in pharmaceuticals with its efficiency in open wound healing and antimicrobial activity. In this study, different concentrations of PG $(1-100 \mu \mathrm{g} / \mathrm{ml})$ were used to evaluate the effect on canine chondrocytes through enzymatic activities of matrix metalloproteinase 2 (MMP-2), MMP-3 and MMP-9 concerning OA. The results showed that both proteolytic activities of MMP-2 and MMP-9 were inhibited significantly using the extract starting at a concentration of $50 \mu \mathrm{g} / \mathrm{ml}$. For MMP-3, enzymatic activity could not be inhibited by the PG extract in canine chondrocytes at any concentration level $(1-100 \mu \mathrm{g} / \mathrm{ml})$. This could suggest that PG extract has a strong potential to inhibit MMP-2 and MMP-9 activities.
\end{abstract}

Index Terms-Canine chondrocyte, MMP-3, MMP-2, MMP-9

\section{INTRODUCTION}

Osteoarthritis (OA) is a chronic joint disease in both humans and animals, which causes suffering and disability involving progressive degeneration of articular cartilage [1], [2]. The cost of medical care has a significant economic impact. The explicit cause of this disease is still unknown, although there are many factors that affect cartilage destruction, such as age, genetics, hormones, obesity and trauma. The inadequate repair response of the extracellular matrix (ECM) like collagen type 2 and proteoglycans, in attempting to repair the worn-away cartilage and chondrocyte apoptosis, will influence the cartilage so as to be degraded and thus develop into OA [3], [4].

Manuscript received April 23, 2012; revised May 31, 2012. This study was financially supported by the National Research University Project under Thailand's Office of the Higher Education Commission.

W. Pradit, P. Siengdee, K. Buddhachat, M. Osathanunkul, and S. Chomdej are with Department of Biology, Faculty of Science, Chiang Mai University, Chiang Mai 50200, Thailand (Tel.: +66 53 941946/48, int. 169; fax: +66 53 941946/48, int. 160; e-mail: siriwadee@yahoo.com).

K. Nganvongpanit was with Department of Veterinary Biosciences and Public Health, Faculty of Veterinary Medicine, Chiang Mai University, Chiang Mai 50100, Thailand.

W. Pradit, K. Nganvongpanit, K. Buddhachat and S. Chomdej are with Materials Science Research Center, Faculty of Science, Chiang Mai University, Chiang Mai 50200, Thailand.
Typically, enzymes related with cartilage degradation are produced in the joints, such as matrix metalloproteinase groups (MMPs). MMPs are a group of zinc dependent extracellular enzymes that have the ability to degrade all components of the extracellular matrix. Among this group MMP-3 genes are up-regulated in the early stage of OA [5, 6], which encodes for stromelysin-1. The enzyme can degrade some extracellular matrix components of cartilage, such as fibronectin, laminin, and collagen types 3, 4, 9 and 10. The study of Aigner et al. [7] found that MMP-2 gene was over-expressed in patients with $\mathrm{OA}$ in the late-stage of disease $(p<0.001)$. Furthermore, both stromelysin-1 and gelatinase A (enzymes that are encoded by the MMP-2 gene) could activate pro-gelatinase $\mathrm{B}$, which is encoded by the MMP-9 gene [8].

Nowadays, the use of medications to relieve pain as well as inflammation for OA treatments is carried out as the basic remedy. However, the cost of these medications is considered expensive, and they also have unwanted side effects. Therefore, herbal medications have been developed to treat arthritis.

In terms of climate, Thailand is in the tropical zone, which allows for a high biodiversity of many species of plants and herbs. Durian (Durio zibethinus) is one of the most favorite fruits in Thailand. Thailand is the world's largest producer and exporter of durian [9]. Thus, waste from durian rinds is a major problem. In 1998, Pongsamart and Panmaung [10] isolated and purified polysaccharide gel (PG) from durian rinds (Durio zibethinus L.). PG is water-soluble saccharides composed of long chain polygalacturonan with branch chain neutral sugars. Acute and subchronic toxicity of long-term, high doses of PG comsuption was examined in mice and rats and the results showed no toxicity $[11,12]$. Recently, the PG has been used in pharmaceuticals such as fibers and film-dressing patches, which were studied in dogs [13] and pigs [14]. In addition, in 2007, durian was first used as an ingredient in skin-care cosmetics as it is capable of decreasing the expression level of the MMP-9 gene, which encodes gelatinase B, an enzyme that could hydrolyze protein components of the skin, such as collagen and elastin [15]. Hence, the objective of this study was to determine the effects of PG extract on enzymatic activities of MMP-2, MMP-3 and MMP-9 proteins. 


\section{MATERIALS AND METHODS}

\section{A. Polysaccharide gel extraction}

Polysaccharide gel was isolated from durian rinds following the method of Hokputsa et al. [16]. Briefly, dry ground fruit-hulls of durians were boiled at $90-100^{\circ} \mathrm{C}$ for 20 min and filtrated through cheese-cloth and a paper filter. Next, the concentration of the filtrate was increased by pressure reduction at $70^{\circ} \mathrm{C}$. The filtrate was precipitated by adding acidified aqueous ethanol followed by filtration, washing with ethanol and then drying. The precipitate was re-dissolved in water, filtered, concentrated, precipitated and dried once again to obtain polysaccharide gel powder.

\section{B. Sample Collection and Cell Culture}

Canine articular cartilages, without OA or other abnormal appearances, were obtained by cutting the leg off using a standard method of veterinary surgery at the Small Animal Hospital, Faculty of Veterinary Medicine, Chiang Mai University, Thailand using the same breed and sex with a body weight range of $10-20 \mathrm{~kg}$ at 2-5 years of age. Primary chondrocytes were prepared according to the method of Siengdee et al. [17] by cutting the cartilage into pieces and digesting with $10 \%$ collagenase type II (Sigma, USA) at $37^{\circ} \mathrm{C}$ for $21 \mathrm{~h}$. Phosphate buffered saline (PBS) was used to wash cartilage pieces, which were then cultured in a $\mathrm{CO}_{2}$ incubator at $37^{\circ} \mathrm{C}$ in Dulbecco's modified Eagle's medium (DMEM) supplemented with $10 \%$ fetal bovine serum (FBS) and 50 $\mu \mathrm{g} / \mathrm{ml}$ gentamicin (GIBCO, USA) for 2 weeks; the media was changed twice a week.

\section{Effect of PG Extract on Canine Primary Chondrocytes}

Cultured cells were trypsinized by trypsin (GIBCO) when the cells reached confluence, and were re-seeded in a 24-well plate for $48 \mathrm{~h}$. Experiments were performed using the first-passage cells, which were washed in PBS before exposure to the PG extract with different concentrations of the extract at $1,10,25,50$ and $100 \mu \mathrm{g} / \mathrm{ml}$ for $24 \mathrm{~h}$ compared with the control group treated with the media instead of PG extract $(0 \mu \mathrm{g} / \mathrm{ml})$. All treatments were performed in triplicate. Collection of cultured media in each group was performed to monitor enzyme activities.

\section{Zymography of Metalloproteinase Activity}

Conditioned media obtained from canine chondrocyte cultures were concentrated and evaluated for protease activities of MMP-2 and MMP-9 by gelatin zymography, and by casein zymography for MMP-3 protein. Protein samples $(20-60 \mu \mathrm{g})$ were loaded equally into each well in $12 \%$ sodium dodecyl sulfate (SDS)-polyacrylamide gel, containing 2 $\mathrm{mg} / \mathrm{ml}$ gelatin or casein (Bio Basic Inc., Canada) with Tris-glycine buffer for $3 \mathrm{~h}$ at $150 \mathrm{~V}$. After electrophoresis, gels were washed twice with $2.5 \%$ Triton X-100 solution for $30 \mathrm{~min}$ at room temperature before incubation in MMP digestion buffer (50 mM Tris- $\mathrm{HCl}, \mathrm{pH} 7.6 ; 200 \mathrm{mM} \mathrm{NaCl} ; 5$ $\mathrm{mM} \mathrm{CaCl} 2 ; 0.02 \% \mathrm{NcN}_{3}$ ) at $37^{\circ} \mathrm{C}$ overnight. The gels were stained with $0.25 \%$ Coomassie Brilliant Blue R250 in 30\% ethanol and $10 \%$ acetic acid for 30-60 min and then destained with $30 \%$ ethanol: $10 \%$ acetic acid until clear bands of proteolytic activity were observed against a dark background of stained gelatin or casein. Finally, the gels were mounted between cellophane sheets and allowed to air dry. Scion Image (Scion, Frederick, MD) was used to evaluate the intensity of each band to verify proteolytic activities.

\section{E. Statistical Analysis}

Relative activities of the 3 MMPs in each treatment were calculated by comparing them with the control group. To evaluate the effects of PG extract on the enzymatic activities of the MMP-2, MMP-3 and MMP-9, one-way analysis of variance (ANOVA) was performed using SPSS version 14.0 (SPSS Inc., USA).

\section{RESULTS}

Cultured media collected for proteolytic activity assays were evaluated using gelatin and casein zymography. After staining with Coomassie Blue, clear bands appeared from substrate digestion of gelatinase (MMP-2 and MMP-9) and stromelysin-1 or caseinase (MMP-3) on the gels (Figure 1); their intensity values were measured to determine protein activities. The results showed that MMP-2 activity was significantly higher than the control group $(p<0.01)$ at 1,10 and $25 \mu \mathrm{g} / \mathrm{ml}$; but when the concentration of the extract was increased to 50 and $100 \mu \mathrm{g} / \mathrm{ml}$, the activity was reduced ( $p<$ 0.01 ). For MMP-3 (stromelysin-1), a higher rate of activities than the control for all treatments $(1-100 \mu \mathrm{g} / \mathrm{ml})$ was detected at a significance of $p<0.01$. For MMP-9 protein activity assay, significant over-expressions at the protein level appeared at 1,10 and $25 \mu \mathrm{g} / \mathrm{ml}(p<0.01)$. On the other hand, treatments with PG extract at 50 and $100 \mu \mathrm{g} / \mathrm{ml}$ showed significantly lower expressions $(p<0.01)$ (Figure 2$)$.

a.

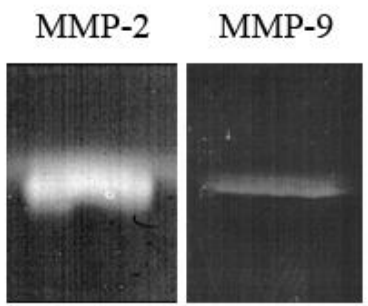

b.
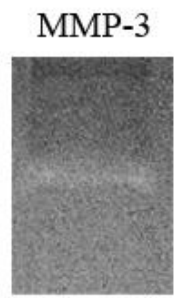

Fig. 1. Clear bands represented enzymatic activities using (a.) gelatin zymography for MMP-2 and MMP-9 showing 72 and $92 \mathrm{kDa}$, respectively and (b.) casein zymography showing $54 \mathrm{kDa}$ of MMP-3.

\section{DISCUSSION}

Osteoarthritis (OA) is a chronic disease of joint degradation with a variety of causes, and there is often great difficulty in finding appropriate treatment methods for a complete cure. Increase of age is one of many factors that seem to have an interaction with the risk for osteoarthritis development. This factor indicates that the age of articular 
cartilage and chondrocyte, provided for the experiment in vitro, influenced the maturity of the cells. Therefore, primary chondrocyte used in this study is most suitable due to its characteristics, which are the most similar to chondrocyte in the animal $[18,19]$. Besides, the first passage of the primary canine chondrocyte was selected to investigate proteolytic activities of MMPs (MMP-2, MMP-3 and MMP-9) using PG extracts at different concentrations (1-100 $\mu \mathrm{g} / \mathrm{ml})$, since morphological changes will occur with increased passages of the cell culture [20] owing to cell trypsinization using collagenase and trypsin that could change phenotypes, reduce the viability rate of cells and decrease synthesis rate of some biochemical substances.

\section{a. $\quad$ MMP-2}

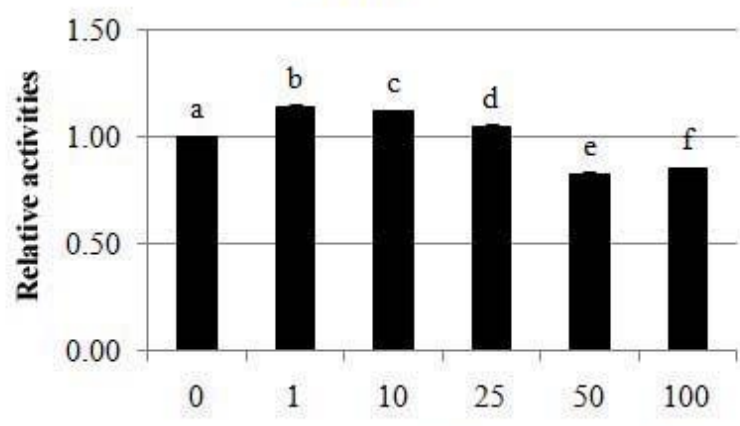

Concentration of PG extract $(\mu \mathrm{g} / \mathrm{ml})$

b.

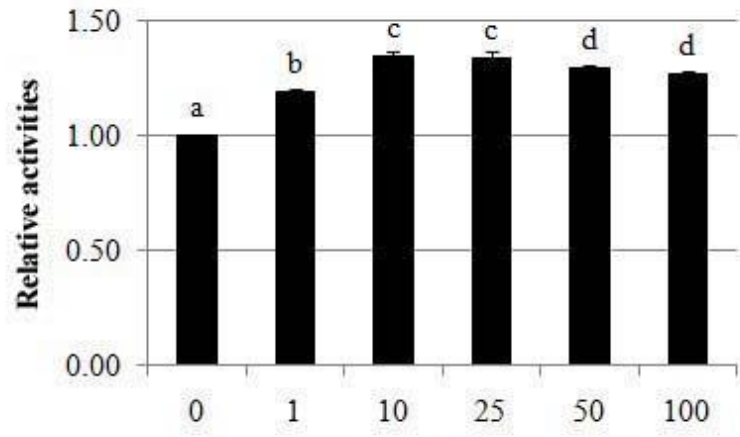

Concentration of $\mathrm{PG}$ extract $(\mu \mathrm{g} / \mathrm{ml})$

C.

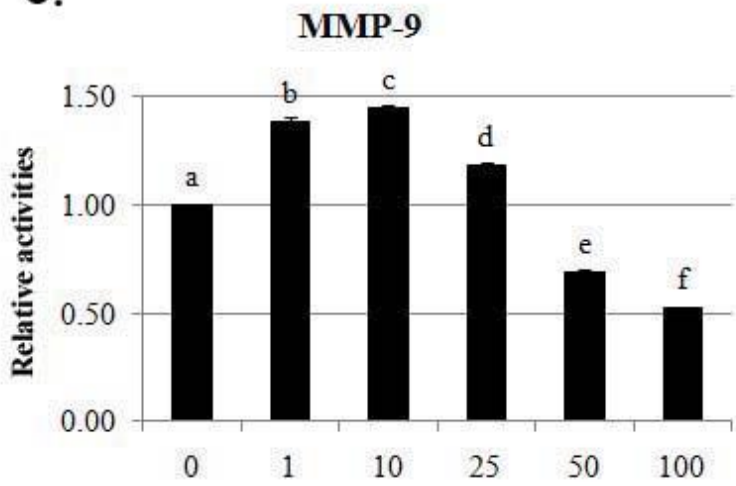

Concentration of PG extract $(\mu \mathrm{g} / \mathrm{ml})$

Fig. 2. Effect of PG extract on the proteolytic activities of (a.) MMP-2, (b.) MMP-3 and (c.) MMP-9 from collected cultured media. The data show the means \pm S.D. values following by different letters as significant at $p<0.05$.
Zymography was used to analyze activity of MMP proteins (MMP-2, MMP-3 and MMP-9) because proenzymes and active enzymes could be distinguished using their molecular weight as the basis, with a higher activity of MMPs due to a binding dissociation of the tissue inhibitor of metalloproteinases (TIMPs) and MMPs through SDS [21]. Furthermore, zymography has other advantages, for instance (1) various enzymatic assays with different molecular weight using the same substrate on a single gel, (2) a short time assay and (3) the use of inexpensive materials [22].

In this study, determination of enzyme activities of MMP-2, MMP-3 and MMP-9 was performed because of their interaction as described by Murphy et al. [8] which claimed that proMMP-9 could be activated to an active form via 3 matrix metalloproteinase enzymes including gelatinase A (MMP-2), collagenase-3 (MMP-13) and stromelysin-1 (MMP-3). MMP-2 and MMP-3 enzymes activate the proMMP-9 (92 kDa progelatinase B) by the same process: by cleavage of proMMP-9 at the $\mathrm{Glu}^{40}-\mathrm{Met}^{41}$ amide bond to generate an $86 \mathrm{kDa}$ intermediate. The second cleavage at the $\mathrm{Arg}^{87}-\mathrm{Phe}^{88}$ bond was performed, resulting in an active 82 $\mathrm{kDa}$ form $[23,24]$.

The results represented in this study have demonstrated that the PG extract could not suppress the enzymatic activity of MMP-3 at any concentration (1-100 $\mu \mathrm{g} / \mathrm{ml})$. This suggested that PG extract had an influence in the activation control of the catalytic activity of MMP-3. There are 6 mechanisms of MMPs regulation that have been reported, including the cysteine switch, allosteric activation, furin activation, activation of proMMPs by MMPs, activation of proMMPs by plasmin and other serine proteinase and oxidative control of MMP activity, but activation mechanisms of MMP-3 was still unknown [25]. In this case, PG extract could not reduce MMP-3 activity in normal canine chondrocytes, which may be due to a disruption in the balance of protein MMP-3 and the tissue inhibitor of metalloproteinase 1 (TIMP-1). TIMP-1 is thought of as a main inhibitor of MMPs, which is working against the function of MMP-3 protein [26], resulting in higher activity of MMP-3 for all concentrations of PG extract. To understand the proportion of MMP-3 and TIMP-1, expression of TIMP-1 in the protein level should be further investigated to unveil the controlling mechanism of MMP-3.

However, expression and activation of MMP-9 was significantly decreased when the cell culture was treated with PG extract at 50 and $100 \mu \mathrm{g} / \mathrm{ml}(p<0.01)$, according to the study of Leverett et al. [15], which showed that the fruit pulp of durian extract at $100 \mu \mathrm{g} / \mathrm{ml}$ could inhibit MMP-9 protein expression induced by tumor necrosis factor alpha (TNF- $\alpha$ ) and transforming growth factor beta (TGF- $\beta$ ) in co-cultures of HS27 (fibroblasts) and HEK001 (keratinocytes).

This study was the first research that demonstrated the effect of PG extract from durian rinds on canine chondrocytes, which had never previously been reported. Further investigations of proteolytic activities of other MMPs concerning osteoarthritis, such as MMP-13 and canine chondrocytes with OA should be evaluated to reveal the effects of PG extract on MMPs activity for osteoarthritis treatment. 


\section{CONCLUSION}

Polysaccharide gel extracted from durian hulls was able to reduce enzymatic activities of MMP-2 and MMP-9 protein treated with concentrations of the extract starting at $50 \mu \mathrm{g} / \mathrm{ml}$. For MMP-3, PG extract could not inhibit proteolytic activity at any of the concentrations used in this study $(1-100 \mu \mathrm{g} / \mathrm{ml})$.

\section{ACKNOWLEDGMENT}

We thank Dr. Raktham Maktrirat for provision of the PG extract. In addition, we gratefully acknowledge the Science Achievement Scholarship of Thailand (SAST) and the Graduate School, Chiang Mai University, Thailand.

\section{REFERENCES}

[1] C. Evans, J. Gouze, E. Gouze, P. Robbins, and S. Ghivizzani, "Osteoarthritis gene therapy," Gene Ther., vol. 11, pp. 379-389, 2004

[2] M. B. Goldring, "Update on the biology of the chondrocyte and new approaches to treating cartilage diseases," Best Pract Res Clin Rheumato., vol. 20, pp. 1003-1025, 2006.

[3] I. F. Petersson, T. Boegård, B. Svensson, D. Heinegård, and T. Saxne, "Changes in cartilage and bone metabolism identified by serum markers in early osteoarthritis of the knee joint," Br J Rheumatol., vol. 37, pp. 46-50, 1998.

[4] S. Hashimoto, R. L. Ochs, S. Komiya, and M. Lotz, "Linkage of chondrocyte apoptosis and cartilage degradation in human osteoarthritis," Arthritis Rheum., vol. 41, pp. 1632-8, 1998.

[5] M. B. Goldring, "The role of the chondrocyte in osteoarthritis," Arthritis Rheum., vol. 43, pp. 1916-1926, 2000.

[6] K. Nganvongpanit, Canine Osteoarthritis. Bangkok, Thailand: Chulalongkorn University Press, 2008.

[7] T. Aigner, A. Zien, A. Gehrsitz, P. M. Gebhard, and L. McKenna, "Anabolic and catabolic gene expression pattern analysis in normal versus osteoarthritic cartilage using complementary DNA-array technology," Arthritis Rheum., vol. 44, pp. 2777-2789, 2001.

[8] G. Murphy, H. Stanton, S. Cowell, G. Butler, V. Knäuper, S. Atkinson, and J. Gavrilovic, "Mechanisms for pro matrix metalloproteinase activation," APMIS, vol. 107, pp. 38-44, 1999.

[9] N. Chomchalow, S. Somsri, and P. N. Songkhla, "Marketing and export of major tropical fruits from Thailand," AU J.T., vol. 11, pp. $133-143,2008$

[10] S. Pongsamart and T. Panmaung, "Isolation of polysaccharides from fruit-hulls of durian (Durio Zibethinus L.)," Songklanakarin J Sci Technol., vol. 20, pp. 323-332, 1998.

[11] S. Pongsamart, S. Sukrong, and A. Tawatsin, "The determination of toxic effects at a high oral dose of polysaccharide gel extracts from fruit-hulls of durian (Durio zibethinus L.) in mice and rats," Songklanakarin J Sci Technol., vol. 23, pp. 55-62, 2001.

[12] S. Pongsamart, A. Tawatsin, and S. Sukrong, "Long-term consumption of polysaccharide gel from durian fruit-hulls in mice," Songklanakarin J Sci Technol., vol. 24, pp. 555-567, 2002.

[13] P. Chansiripornchai and S. Pongsamart, "Treatment of infected open wounds on two dogs using a film dressing of polysaccharide extracted from the hulls of durian (Durio zibethinus Murr.): case report," Thai J Vet Med., vol. 38, pp. 55-61, 2008.

[14] P. Chansiripornchai, C. Pramatwinai, S. Pongsamart, O. Nakchat, and A. Rungsipipat, "The efficiency of polysaccharide gel extracted from fruit-hulls of durian (Durio zibethinus Linn.) for wound healing in pig skin," The $3^{\text {rd }}$ world Congress on Medicinal and Aromatic Plants for Human Welfare, (Chiang Mai, Thailand, 2003), pp. 5-14.

[15] J. Leverett, A. Chandra, J. Rana, D. J. Fast, S. R. Missler, and D. M. Flower, "Extracts of durian fruit for use in skin care compositions," (United States, 2007).

[16] S. Hokputsa, W. Gerddit, S. Pongsamart, K. Inngjerdingen, T. Heinze, A. Koschella, S. E. Harding, and B. S. Paulsen, "Water-soluble polysaccharides with pharmaceutical importance from durian rinds (Durio zibethinus Murr.): isolation, fractionation, characterisation and bioactivity," Carbohydr Polym., vol. 56, pp. 471-481, 2004.

[17] P. Siengdee, K. Nganvongpanit, P. Pothacharoen, S. Chomdej, S. Mekchay, and S. Ong-Chai, "Effects of bromelain on cellular characteristics and expression of selected genes in canine in vitro chondrocyte culture," Vet Med (Praha)., vol. 55, pp. 551-560, 2010.

[18] S. Yang, S. Ahn, J. Rhie, K. Lee, J. Choi, and B. Lee, " Platelet supernatant promotes proliferation of auricular chondrocytes and formation of chondrocyte mass," Ann Plast Surg., vol. 44, pp. 405-411, 2000.

[19] M. Frohlich, C. Mali, M. Gorensek, M. Knezevic, and V. Kregar, "Evaluation of rabbit auricular chondrocyte isolation and growth parameters in cell culture," Cell Biol Int., vol. 31, pp. 620-625, 2007.

[20] K. V. D. Mark, V. Gauss, H. V. D. Mark, and P. Müller, "Relationship between cell shape and type of collagen synthesised as chondrocytes lose their cartilage phenotype in culture," Nature, vol. 267, pp. 531-532, 1977.

[21] P. A. M. S.-V. Beurden, and J. W. V. d. Hoff, "Zymographic techniques for the analysis of matrix metalloproteinases and their inhibitors," BioTechniques, vol. 38, pp. 73-83, 2005.

[22] J. Wilkesman and L. Kurz, "Protease analysis by zymography: a review on techniques and patents," Recent Pat Biotechnol., vol. 3, pp. 175-184, 2009.

[23] Y. Ogata, J. J. Enghild, and H. Nagase, "Matrix metalloproteinase 3 (stromelysin) activates the precursor for the human matrix metalloproteinase 9," J Biol Chem., vol. 267, pp. 3581-3584, 1992.

[24] R. Fridman, M. Toth, D. Peña, and S. Mobashery, "Activation of progelatinase B (MMP-9) by gelatinase A (MMP-2)," Cancer Res., vol. 55, pp. 2548-2555, 1995.

[25] H.-J. Ra and W. C. Parks, "Control of matrix metalloproteinase catalytic activity," Matrix Biol., vol. 26, pp. 587-596, 2007.

[26] K. Nganvongpanit, P. Chaochird, P. Siengdee, P. Pothacharoen, K. Klunklin, S. Chomdej, S. Mekchay, and P. Kongtaweelert, "In vitro suppression of the MMP-3 gene in normal and cytokine-treated human chondrosarcoma using small interfering RNA," $j$ Orthop Surg Res., vol. 4, pp. $45,2009$. 